\title{
专访全球绿色化学代表人物: 李朝军院士
}

\author{
《物理化学学报》编辑部 \\ 北京大学化学与分子工程学院, 北京 100871
}

\section{Interview with the Leader of Global Green Chemistry: Academician Chao-Jun Li}

\author{
Editorial Office of Acta Physico-Chimica Sinica \\ College of Chemistry and Molecular Engineering, Peking University, Beijing 100871, P. R. China. \\ Email: whxb@pku.edu.cn.
}

Published online: April 11, 2019.

绿色化学，是上世纪90年代新兴的一门多学科交叉领域，更是21世纪的重要主题之一。绿色化学在协 调经济、资源、环境三者矛盾的过程中, 发挥着日益重要的作用。绿色化学的发展将有效促进化学及相关 学科的重大发展, 并引起化学化工行业的变革。我们有幸采访了全球绿色化学代表人物, 同时也是《物理 化学学报》编委——李朝军院士, 为我们分享他的研究经历及对国内外绿色化学行业的分析。

Question 1: Professor Li, when did you start your research in the field of green chemistry? Please describe briefly the key achievements and major ongoing projects of your research group in the field of green chemistry.

Answer: I was fortunate to start my research at the dawn of the green chemistry. During my years as a PhD student at McGill University, I was fascinated by the great achievements in natural product total synthesis, but overwhelmed by the complexity and difficulty to synthesize these compounds. I was wondering if there are easier ways. While trying to pick a research subject for my PhD at McGill, my PhD advisor (Prof. Tak-Hang Chan) and I were inspired by Prof. R. Breslow's research on Diels-Alder reactions in water, and want to try Grignard-type reactions in water, which would greatly simplify many syntheses by avoiding protection-deprotections steps if successful. I subsequently discovered the indium-mediated reactions in water, which (was called by the "Li-Chan protocol" by Prof. G. M. Whitesides at Harvard University) has become a very popular reaction. Afterwards, I tried to collect all literatures for organic reactions in water and wrote the first comprehensive review. Initially, I put Prof. Chan's name on it but he insisted to publish by myself after making suggestions, a great gentleman. This came out in Chemical Review in 1993 and attracted a lot of interest, because the concept of Green Chemistry just appeared.

One of the key research achievements in my independent career is the development of the Grignard-type reaction in water into a highly successful field as the initial study is only restricted to allylation reaction. Among them, one of the highlights is the development of the Alkyne-Aldehyde-Amine coupling (we named $\mathrm{A}^{3}$-coupling) in water, which allows such a reaction directly on sugar, amino acids, and other biological molecules. Another high point in my career is the development of the concept of Cross-Dehydrogenative Coupling (CDC) reaction. Previous $\mathrm{C}-\mathrm{C}$ bond formation reactions rely exclusively on functional groups (require one or two functional groups). For the first time in 2004, we described that future $\mathrm{C}-\mathrm{C}$ bond formations for chemical synthesis could be accomplished by simply using two different $\mathrm{C}-\mathrm{H}$ bonds via the selective formal removal of $2 \mathrm{H}$, namely $\mathrm{CDC}$ reactions. If successful, such reactions will allow the great simplification and increased efficiency of future chemical syntheses and minimize waste and cost associated with chemical manufacturings. We also succeeded various early examples. This subject has subsequently become one of the hottest research areas in organic chemistry. Other achievements in our lab include the discovery of direct coupling of phenols (readily available from renewable biomass) with amines, umpolung of carbonyls as organometallic reagents surrogates for various reactions, and light-enabled room temperature conversions of (nitrogen to ammonia, methane to benzene, and methanol to ethanol, among others).

Question 2: Who has influenced you the most in your research efforts?

Answer: The great ancient Chinese philosopher，老子。

Question 3: Please describe the major difficulties that you 
have encountered in your research career.

Answer: When you are working on a "hot subject", everyone recognizes its importance. However, when you start working on a totally new subject, it is difficult to be appreciated at first by journals and reviewers, until it becomes "hot".

Question 4: In your opinion, what are the most important research findings in the field of green chemistry over the previous decade?

Answer: There are many important achievements in the last decade. If only picking one, I would choose the discovery of perovskite materials for solar energy capturing.

Question 5: Compared to international achievements in the field, what is the current level of achievement of green chemistry research in China?

Answer: Researchers in China have made great achievements in many areas of green chemistry. Overall, green chemistry research in China is on the same level as and more advanced in some areas than international ones, especially towards applications.

Question 6: What are the unique aspects of domestic and international research in green chemistry?

Answer: In many aspects, the domestic researches and international researches are similar. However, one unique aspect of the domestic researches is that many of them are closer to practical applications, and also research results are used more rapidly, partly due to the fast economic development domestically.
Question 7: What are the biggest challenges to be overcome in the development of the field of green chemistry?

Answer: Highly efficient capturing of renewable energy and highly efficient transformation of renewable and abundant feedstocks into chemicals and material needs of our society are probably the biggest challenges in the field of green chemistry.

Question 8: In your opinion, how will the development and application of green chemistry influence our living environment?

Answer: Economic development is central to any society. However, our future development is facing great scientific challenges in three key scientific areas: dwindling material resources, shortage of energy, and deterioration of the environment. Green chemistry is one of the key fields that try to develop new sciences and technologies that can maximize resource and energy utilizations, and at the same time minimizes the environmental impact of chemical productions and usages at the most fundamental level.

Question 9: Do you have any advice for young researchers?

Answer: It feels nice to do research in a "hot area" at the beginning; but in the long run, it may pay off to work on a "cold" and unrecognized subject.

Question 10: What are your hobbies and personal interests?

Answer: I was planning to be an artist (艺术家) before becoming a chemist in the university. Thus, although I rarely do painting and drawings now, I still like all things that are artistic and hope to pick it up again when I retire in future.

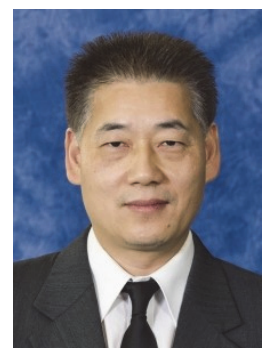

李朝军，加拿大皇家科学院院士，发展中国家科学院院士，美国科学促进会会士，美国化学会会 士，英国皇家化学会会士，及加拿大化学化工学会会士。1983年毕业于郑州大学化学系，1988年中国科 学院化学研究所研究生毕业, 1992年在加拿大McGill大学获得博士学位。1992至1994年在美国斯坦福大 学Barry M. Trost教授小组从事NSERC博士后研究。1994年任美国杜兰大学助理教授、1998年任副教 授、2000年起任教授。2003年起任麦吉尔大学教授、加拿大绿色化学首席科学家, 2009年起任麦吉尔大 学E. B. Eddy讲座教授。曾任加拿大Green Chemistry and Engineering Network共同主席、NSERC绿色化学 中心主任、及现任FQRNT绿色化学与催化中心共同主任。

李朝军院士曾获得美国总统绿色化学挑战奖，2006年“科学美国人”杂志将他列为全球绿色化学领域的5位著名科学家之 一, 2007年, 加拿大化学会将其研究成果列为二十世纪20项加拿大最重要的与化学相关的科学发现之一; 2010年获得了加拿 大绿色化学与工程奖等。任Green Chemistry (RSC)副主编、McGraw-Hill's Encyclopedia of Sciences and Technologies, McGrawHill's Year Book of Sciences and Technologies, Chemical Sciences, Chemical Society Review等顾问编委、《物理化学学报》编 委。他长期致力于 “水相有机化学” 及 “原子经济性” 的绿色化学有机合成研究。发表了 400 余篇研究论文, 被引用 40000 余次, H-index = 98 (2019年3月)。另外, 他应邀在各种国际会议上及大学作了 400 多次大会报告、主题报告和邀请报告, 并 已出版7本专著。 